\title{
Frequency and seasonality of flash floods in Slovenia
}

\author{
Tajan Trobec ${ }^{A}$ \\ Received: June 30, 2017 | Revised: August 10, 2017 | Accepted: August 28, 2017
}

DOI: $10.5937 / g p 21-16074$

\begin{abstract}
The purpose of this paper is to assess and analyse the dynamics of flash flooding events in Slovenia. The paper examines in particular the frequency of flash floods and their seasonal distribution. The methodology is based on the analysis of historical records and modern flood data. The results of a long-term frequency analysis of 138 flash floods that occurred between 1550 and 2015 are presented. Because of the lack of adequate historical flood data prior to 1950 the main analysis is based on data for the periodbetween1951 and2015, while the analysis of data for the period between1550 and1950 is added as a supplement to the main analysis. Analysis of data for the period after 1950 shows that on average 1.3 flash floods occur each year in Slovenia. The linear trend for the number of flash floods is increasing but is not statistically significant. Despite the fact that the majority of Slovenian rivers have one of the peaks in spring and one of the lows in summer, $90 \%$ of flash floods actually occur during meteorological summer or autumn - i.e. between June and November, which shows that discharge regimes and flood regimes are not necessarily related. Because of the lack of flood records from the more distant past as well as the large variability of flash flood events in the last several decades, we cannot provide a definitive answer to the question about possible changes in their frequency and seasonality by relying solely on the detected trends. Nevertheless, considering the results of analysis and future climate change scenarios the frequency of flash floods in Slovenia could increase while the period of flash flood occurrence could be extended.
\end{abstract}

Keywords: flash floods, historical flood records, flood frequency, flood seasonality, climate change, Slovenia

\section{Introduction}

Floods are a natural phenomenon and as such are a geomorphological factor in the transformation of the natural landscape. We are often only aware of them when we are directly in their way and they damage our property or endanger human life.The common concern of nowadays is that globally floods are causing more and more damage (Mills, 2005), whilst fatalities are also very common (EM-DAT, 2009). In the 21-year period between 1995 and 2015 floods alone affected 2.3 billion people worldwide and killed at least 157,000 (UNISDR \& CRED, 2016).Because flash floods occur suddenly, of- ten without warning, encompassing rapid increases in water level and water flow, erosion, transportation and deposition of large amounts of different fluvial materials, they are among the most dangerous types of floods (Borga, et al., 2014). On average, at least 5,000 people die annually as a result of flash floods (Jonkman, 2005). In humid climate conditions in temperate latitudes flash flooding occurs as a result of extremely heavy and intense precipitation in a relatively small area (Borga, et al., 2007, 2008). In general it affects headwater catchments of smaller watercourses that range in size from 10 to a few $100 \mathrm{~km}^{2}$ (Modrick, Georgakakos, 2016).

\footnotetext{
A Department of Geography, Faculty of Arts, University of Ljubljana, Aškerčeva cesta 2, SI-1000 Ljubljana, Slovenia; tajan.trobec@ff.uni-lj.si
} 
The frequency of floods in Europe and the serious damage they cause, have attracted the attention of many researchers (to name just a few: Barredo, 2007; EEA, 2016; Gaume, et al., 2009; Kundzewicz, et al., 2013). In recent years Europe has relatively frequently been affected by extensive flooding with a return period over 100 years (Grams, et al., 2014). After virtually every extreme flooding event, whether it is a flash or riverine flood, again the question arises about the apparent increase in the frequency of floods, which is generally attributed to climate change. In response to this question a number of studies into changes in flood regimes have emerged looking at various parts of Europe, as well as individual countries, catchments or groups of catchments, which examine trends in the frequency, magnitude and seasonality of extreme flows and floods. The results of these studies have been summarised in a number of review articles (e.g. Brázdil, et al., 2006; Brázdil, et al., 2012; Hall, et al., 2014; Kjeldsen, et al., 2014; Madsen, et al., 2014).

Authors of studies into changes in flood regimes have utilised varying methodological approaches taking into consideration data availability for different periods. For most European rivers, systematic monitoring of flows only began around the turn of the 2oth century (Brázdil, et al., 2012). For the instrumental period most studies that have been completed analysed the trends of annual maximum flows (e.g. Petrow, Merz, 2009; Blöschl, et al., 2012). Alongside these, studies have also been conducted that have relied on historical flood records (e.g. Glaser, et al., 2010; Melo, et al., 2014). Some studies have focused on examining the seasonal incidence of extreme flow and flood events (e.g. Blöschl, et al., 2017; Macdonald, 2012; Parajka, et al., 2010), mostly in connection with investigations into flood generating processes. Flash floods are specific as they occur alongside lower order watercourses in steep terrain landscapes, where there are often not even water gauging stations (Gaume, et al., 2009). They regularly affect remote areas, which is also why a significant proportion of these floods is not documented in historical records. As a result, only some of the mentioned studies focus directly on flash flooding (e.g. Archer, et al., 2016; Bryndal, 2015; Llasat, et al., 2010; Marchi, et al., 2010; Solín, 2008).

Due to differences in methodologies, different flood indicators used and different periods being analysed it is difficult to directly compare results of studies into changes of flood regimes. What is more, flooding across Europe occurs at different times of the year and likewise is the result of different flood generating processes (Blöschl, et al., 2017). Making comparisons is made even more difficult by the fact that in addition to climate change, changes in flood regimes have also been influenced by interventions in watercourses and land use changes (Merz, et al., 2012). The impact of these factors affecting flood regimes can also vary depending on geographical location, altitude and size of catchments. However, despite the evident increase in the intensity of rainfall (Medsen, et al., 2014), it is not possible (at least for now) to unequivocally confirm that extreme flows are increasing in Europe as a whole given that there are many contradictory findings (Hall, et al., 2014; Kundzewicz, 2012).

The study area of this paper is the country of Slovenia, which lies at the junction of four major natural units, namely the Alps, the Mediterranean, the Dinaric Mountains, and The Pannonian Basin (Figure 1). Approximately $80 \%$ of Slovenian territory drains through Sava river and its tributaries into the Black Sea (consequently belonging to Danube river basin), while the remaining $20 \%$ is drained into the Adriatic Sea.

In terms of damage caused, flooding falls immediately after droughts and hail events at the top of the list of natural disasters in Slovenia (Zorn, Komac, 2011). In mountainous and hilly parts of the country, especially in the highland Alps and subalpine mountains, there are many torrential streams where during excessive rainfall flash flooding can occur (Trobec, 2016). Slovenia is characterised mainly as a headwater region. Because of specific physiographic structure of most of the river basins (i.e. the relatively steep slopes and/or impermeable bedrock) which are typically associated with rapid runoff, flash floods are the prevailing type of floods along the majority of Slovenian watercourses (Brilly, et al., 1999). By some estimations (e.g. Komac, et al., 2008) more than one eighth of the entire Slovenian territory is threatened by potential flash flooding.

In recent times Slovenia has been hit by some fairly extensive and intense flash floods, which were also recognised internationally (e.g. Zanon, et al., 2010). Due to the practically annual occurrence of floods, significant material damage that this causes and large media visibility, the prevailing opinion is that floods are increasingly frequent and violent (Natek, 2007). To date several authors have examined the issues of flood frequency and seasonality in Slovenia. Kolbezen (1996) for instance observed that the frequency of floods with catastrophic consequences had not been increasing until the mid-199os. Analysis of river discharge rates after 1996 suggests increasingly frequent high water events or the so-called flood warning level discharge, where rivers begin to flood in flood-prone areas (Kobold, 2011). Moreover, the discharge peaks are increasingly approaching historical records and occasionally exceeding them in certain catchments. This is particularly true for small watercourses along which flash flooding occurs. On the other hand, Frantar, et al. (2008) argue that in selected water gauging 


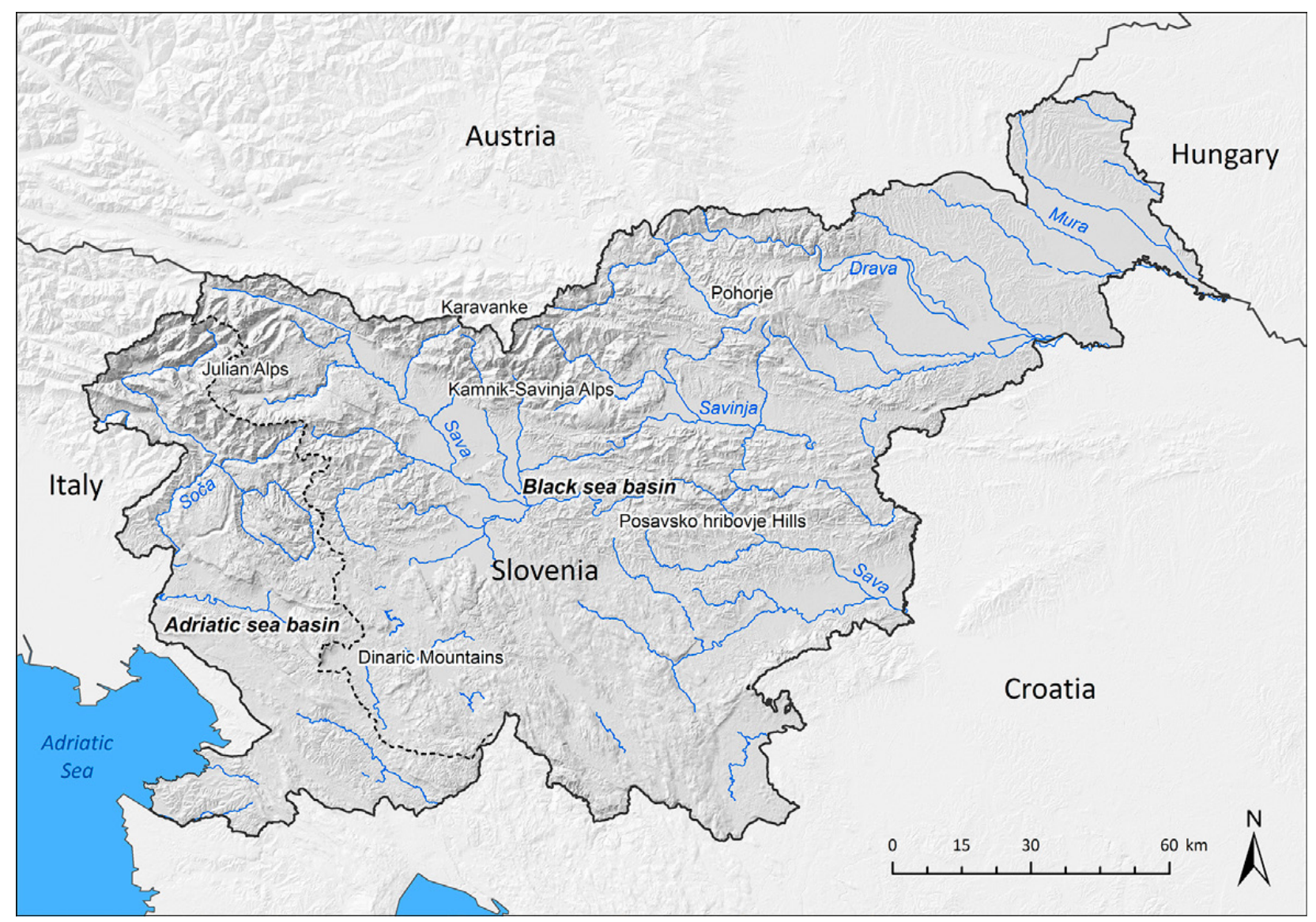

Figure 1. Study area - the country of Slovenia

stations with long-term datasets neither the analysis of annual mean-daily maximum discharge trends nor the frequency of extreme discharges point to a statistically significant increase in flood risk. Similar conclusions were also reached by Šraj, et al. (2016) who found a statistically significant increasing trend of 10year return period discharges in only $5 \%$ of studied gauging stations.

In Slovenia flash floods occur with varying frequency during different times of the year due to specific climatic conditions (Ogrin, 1996) with a variety of seasonally dependent weather processes that generate heavy and intense precipitation and associated flash flooding. Most of the literature suggests that floods in Slovenia occur mainly in spring and autumn - when they are most frequent and severe (Mikoš, et al., 2004), but also in summer, when flooding is typically of the flash flooding type (Bat, et al., 2003; Brilly, et al., 1999; Kolbezen, 1998). Furthermore, in different parts of the country seasonal flash flooding occurs at a varying frequency. Trobec (2016), for example, notes that autumnal flash floods occur across most of the country, while summer flash floods occur primarily in the East, where to a greater extent one can already see the influence of continental climatic factors.

Projections from models of current climate trends for Europe predict there will be increasingly intense precipitation and increasing frequency of all types of floods, including flash floods (Stocker, 2014). In some areas significant changes in the seasonality of extreme flows and floods are reported (Blöschl, et al., 2017; Arheimer, Lindström, 2015; Petrow, Merz, 2009; Macdonald, 2012), which suggests that in these areas future floods might occur more frequently in times of the year, not typically associated with flooding. In this context Hall, et al. (2014) point to flood frequency, together with changes in flood seasonality as key variables in preparing flood management strategies for the future. Studying historical flood dynamics in a specific area provides a basis for examining how they change in the future. Along with studying changes in dynamics of extensive river flooding, greater attention should also be paid to local flash floods. Given their already mentioned specific characteristics, collecting data on such floods is difficult (Borga, et al., 2008), which also means they have not been studied to the same degree (Gaume, et al., 2009). In addition, in line with current trends of increasing intensity of precipitation, which is the main cause of flash floods, it is reasonable to expect that there will be more flash floods in Europe in the future and that the damage they cause will increase and affect a greater number of people.

In this paper we examine the frequency and seasonal distribution of flash floods in Slovenia. The method- 
ology is based on the analysis of historical records and modern flood data. The results of analyses of 138 flash floods that affected the territory of Slovenia between 1550 and 2015 are presented. We particularly focused on the period after 1950, assuming that for this period data for the vast majority of major flash floods are available. Based on results of our analyses and projected climate change scenarios (Kajfež-Bogataj, et al., 2004; Stocker, 2014) we also endeavour to provide a rough estimate of possible future dynamics of flash flooding events in Slovenia in terms of their frequency and seasonal distribution.

\section{Data and Methods}

Since the annual maximum flow and similar flood indicators, which are usually used as a surrogate for floods, does not always represent neither an out-of-bank flow (Pińskwar, et al., 2012) let alone the devastating flash floods, in this study only actual flood events are considered. The data used to analyse flash flooding events in Slovenia were sourced from existing resources and literature. From an extensive range of different records, descriptions and previous studies of floods in Slovenia we selected those, for which it was possible to discern or at least indirectly infer that they would be classed as flash floods. Since karst and riverine floods were not the objects of our study, we excluded them from the analysis, despite the fact that the latter occasionally followed flash flooding, albeit with a lag, particularly following extended autumnal rainfalls.

Data on earlier floods were mainly gathered from secondary sources (i.e. Jesenovec, 1995; Kolbezen, 1991; Kolbezen, 1992; Kolbezen, 1993; Kolbezen, 1994; Kolbezen, 1995; Trontelj, 1997) such that primary sources (public media, records of provincial administrative bodies, archival records of daily newspapers, chronicles, archives of the former Hydrometeorological Institute of the Republic of Slovenia (nowadays Slovenian Environment Agency (SEA)),...)) which were referenced by these sources have not been listed. For floods, which occurred in recent decades, we also relied on primary sources, particularly on certain contributions to scientific and professional journals and anthologies, such as Geografski vestnik [Geographical Bulletin], Geografski zbornik [Journal of Geography], Ujma [Magazine on the protection against natural and other disasters], and others, as well as on various reports and publications from the SEA website (SEA, 2016).

In the case of local flash flooding, which usually occur in the warmer part of the year when precipitation is induced or enhanced by convection, we were able to attribute individual floods to the exact day of their occurrence since lag time between precipitation and con- sequent flooding was rather short. In contrast, when it comes to flooding that occurred as a result of slow travelling large frontal or cyclonic systems causing prolonged precipitation with different and varying local intensity (usually in the colder part of the year), several individual floods were considered as a single flood event, despite them occurring on different days and/or in different catchments, and they were all attributed to the day when, in view of the current synoptic situation, flooding was most severe. In this way, we increased the transparency of the database, as individual scattered flooding was linked to a common cause, i.e. precipitation as part of the broader precipitation system.

From available sources we selected 138 flash floods, which were recorded in the period between 1550 and 2015. The data collected enabled us to carry out an analysis on the frequency of past flash floods. The sample was not perfect, however, it is likely that it included most of the recorded major flash floods to have occurred in Slovenia (especially since 1950). Because of the lack of adequate historical flood data prior to 1950 the main analysis is based on data for the period between 1951 and 2015, while the analysis of data for the period between 1550 and 1950 is added as a supplement to the main analysis.

For 124 of the floods, in addition to the year, it was also known in which month the event had occurred. This was critical in enabling analysis of the seasonal distribution of flash floods. We also determined in which meteorological season floods occurred. Meteorological seasons are named after astronomical (common) seasons, but they do not correspond to them in terms of when they begin and end. Rather, they cover discrete three-month periods. Meteorological winter represents the period between December and February, meteorological spring between March and May, meteorological summer between June and August and meteorological autumn between September and November. Classifying flooding according to meteorological seasons instead of astronomical allowed us to determine the season of occurrence for floods that had a known month, but not date of occurrence. In this way we, were able to increase the sample of our analysis, and thus obtain a clearer insight into the seasonal distribution of past flash flooding in Slovenia.

\section{Results}

\section{Frequency of flash floods}

Flash flooding is currently receiving a lot of media attention in Slovenia. Though we cannot associate it singularly with present times, since devastating floods occurred relatively often in the past as well and, as is true of today, sparing neither man's property nor 

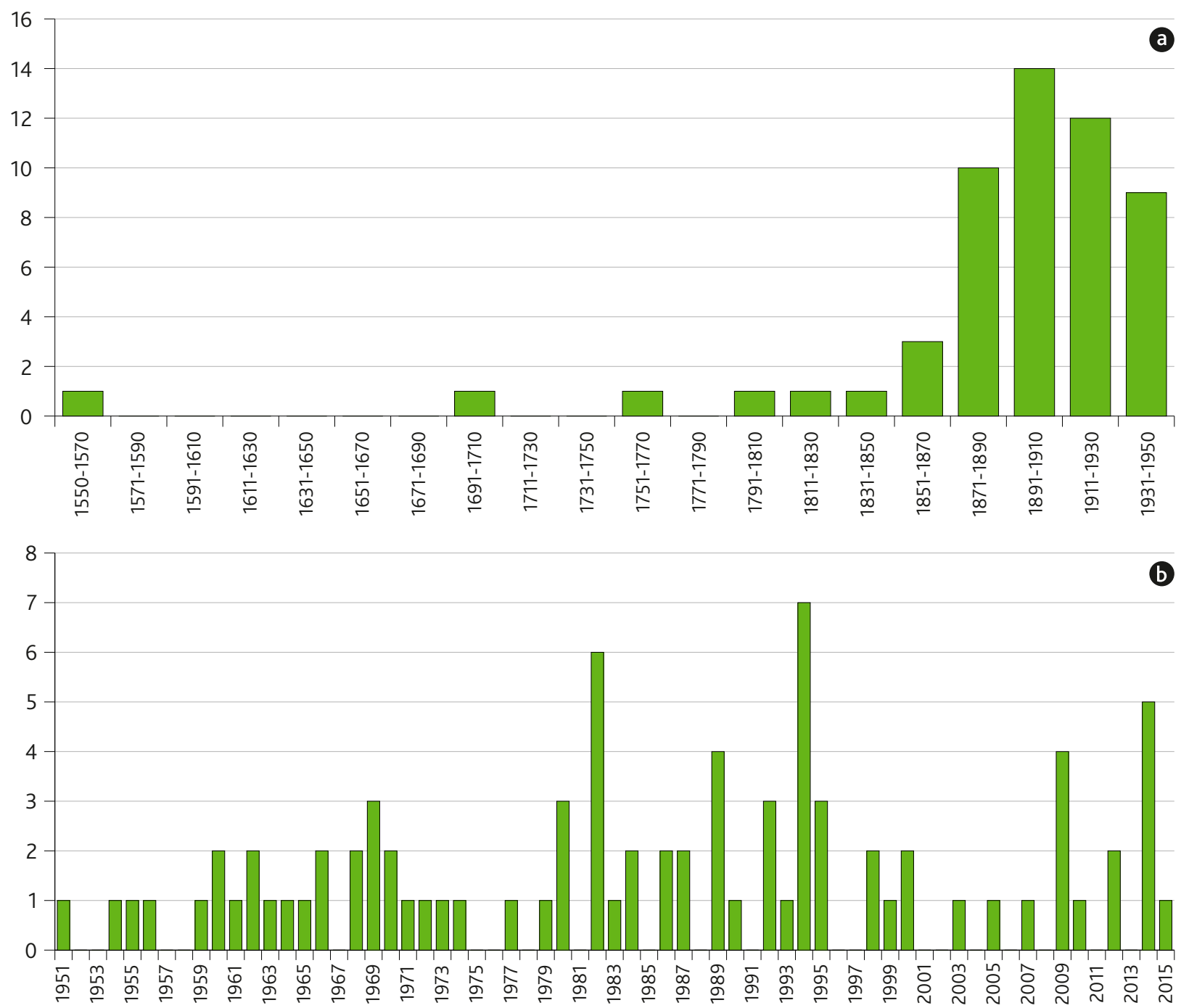

Figure 2. Number of flash floods in Slovenia between 1550-1950 (a) and between 1951-2015 (b).

Source: author's survey

other infrastructure, while occasionally also claiming human lives. That said, the further back in time we go, there are fewer and fewer records of flash floods in Slovenia. Moreover, they mostly refer to more catastrophic and severe events. Subsequent descriptions of floods are more numerous and consistent. For example, there is only one recorded flash flooding event in the 16 th century and none in the 17 th century. There are then two mentions of flash flooding in the 18th century. In the 19th century, 24 flash floods were mentioned in different sources, while reports on floods become even more numerous in the 2oth century with 95 flash flood descriptions available.

Descriptions of flash floods becoming more and more common over time gives a false impression that the frequency of flash flooding has been continuously and significantly increasing over the centuries (Figure 2). The true picture of changes in the frequency of flash flooding over the centuries is further distorted by the fact that societies have become increasingly vulnerable to flooding. Over the centuries the popula- tion has increased, which likely resulted in increased population density in flood-prone areas. In addition, human activities, such as logging, expansion of arable land, settling in higher and steeper areas, land development, etc., had a significant impact on the river regime in terms of increased erosion and accumulation. In many places, the latter led to an expansion of the flood-prone area in valleys and consequently to an increased threat in some settlements, which were not the subject of flooding in more distant past (Šifrer, 1983). Due to insufficient sources from the more distant past and human intervention in the environment, it is impossible to either confirm or reject hypotheses about the changes in frequency of flash flooding over the centuries solely on the basis of analysing existing records of past flash flooding.

If, on the other hand, we assume that after 1950 data on the majority of the major flash floods is for the most part accurate and complete and that 65 years (that have since passed) is long enough to presuppose the dynamics of flash flooding, we can nevertheless 
use data from this period to draw a few general observations for Slovenia. From 1951 to 2015, Slovenia was hit by at least 84 flash floods, which means 1.3 flash floods on average per year. There were occasionally years with multiple flash floods. In this regard, the most notable years were 1994, when there were seven flash floods, 1982 with six flash floods, and 2014 with five flash floods. Interestingly years with the most recorded flash floods fall after 1980, which may probably be related to both natural variability of flash floods and the impact of climate change with associated increases in precipitation intensity.

The linear trend for the period 1951-2015 generally exhibits a slow increase in the number of flash floods, but the trend is not statistically significant ( $p>0.05$ ) (Figure 2 (b)). At the beginning of the period, based on the linear trend line, there was on average around one flash flood annually, while at the end of the period the figure had risen to 1.6 flash floods per year. This raises the questions: to what extent does the upward trend actually represent an increase in the number of floods; to what extent is this a consequence of potentially undocumented floods in the early years or decades of the period; and, to what extent is it a consequence of the increased presence of humans and their activities, in other words, the increased vulnerability of communities in flood-prone areas?

It is undoubtedly possible that in the early years or decades after 1950 some floods were not recorded and were therefore not included in the analysis. However, we conclude that, because it is a relatively recent period and the media coverage of the time was satisfactory, these could not be so numerable that their exclusion would significantly affect the results of the analysis. On the other hand, the vulnerability of communities in flood-prone areas was still increasing after 1950 due to various factors. Especially after the Second World War people were immigrating to floodprone areas in the vicinity of torrential watercourses, where they were followed by industry and infrastructure (Komac, et al., 2008). In certain areas, compared to the past, when flood waters did not reach and affect humans and their activities, in recent decades they have become fatal as a result of careless placement of different activities in landscape. Various structural flood protection measures present another important factor. Whilst they more or less successfully protect against floods, in many areas they further exacerbate the torrential character of watercourses. However, by examining the causes and consequences of individual floods during this period, we came to the conclusion that the increased presence of humans and their activities along with their interference with river basins and watercourses increased merely the damage caused by floods but not their frequency.
Below are the data for the final 15-year period between 2001 and 2015, for which we are confident that figures on flash flood numbers are completely reliable, since there was an abundance of various resources at our disposal. In this period there were 16 flash floods in total; 1.1 per year on average. It is less than the 1.3 flash floods per year, the average for the entire period 1951 to 2015, and considerably less than for instance 2.1 floods per year over the 15-year period between 1981 and 1995, when flash flooding was most frequent (a total of 32 floods during this period). Listed findings clearly reveal that, despite an overall upward trend in the frequency of flooding, in the early $21 s t$ century it was actually somewhat lower compared to the entire period between 1951 and 2015. Given the relatively large variability when it comes to past flood events as well as the expected increases in precipitation intensity as a result of climate change (KajfežBogataj, et al., 2004; Stocker, 2014), this trend may actually shift in future. Besides, flooding during the first 15 years of the 21st century may not stand out in terms of frequency, whilst on the other hand, this period is marked by an outstanding number of severe floods that resulted in substantial material damage as well as casualties. Such were for instance the 2005 floods in Posavje region (Kobold, 2006), the 2007 floods in Železniki (Zanon, et al., 2010), the 2010 (Kobold, 2011) and 2012 floods covering much of the country, and the 2014 floods in the western subalpine region (SEA, 2016).

In addition, projected impacts of climate change for the territory of Slovenia generally forecast an increase of up to $30 \%$ in peak discharges in alpine and subalpine regions by the end of the 21st century (Kobold, 2009). Due to specific geographical conditions and consequent frequent incidence of flash flooding, these areas are already bearing the brunt of flooding. While, in addition to increased flow peaks we are also likely to see significantly increased frequency of flooding itself. Alfieri, et al. (2015) predict that, compared to 1990, the frequency of floods with a return period over 100 years will triple by 2020 and increase by a factor of five by 2050. These figures place Slovenia alongside Iceland, Switzerland and Netherlands, which have the highest rates for European countries, significantly above the average for the rest of Europe. In Slovenia we should therefore expect frequent and violent flash floods in future.

\section{Seasonal distribution of flash floods}

Flash floods in Slovenia are characterised by marked seasonality. Taking into account only floods, where data on their month of occurrence is available (124 floods), $87 \%$ of floods between 1550 and 2015 occurred within the six-month period between June and No- 
vember, which corresponds to meteorological summer and autumn. During the entire period, at least one flash flood occurred in each and every month of the year (Figure $3(e, f)$ ). Looking at available sources, we can conclude that flash floods occurring outside of the common period of occurrence were, on average, no less destructive than those that occurred between June and November. It means that the time of flooding does not seem to have a decisive role on flood severity.

The existing seasonal distribution of flash floods is a result of Slovenia's climatic characteristics. In terms of Slovenia's climate classification it is situated at a transition point between Mediterranean and Central Continental Europe, while in the highest mountains it also exhibits the effects of Alpine climate (Ogrin, 1996). Different weather conditions, usually associated with a specific part of the year, lead to the formation of heavy and intense precipitation and associated flash flooding. Generally speaking, weather events in Slovenia are most intense during meteorological summer, when air is able to absorb more moisture due to high temperatures, which is then released in the form of intense precipitation. During this period, flash floods usually occur as a result of storms with heavy downpours, most frequently due to the passage of a cold front or the proximity of a cut-off low (Petkovšek, Trontelj, 1996). Convection often plays a decisive role in causing high intensity precipitation in this part of the year as a result of air overheating near the ground. During meteorological autumn the formation of precipitation that results in flash flooding is also often propagated by the passage of cold fronts, especially when these slow down considerably over the Alps, or when they spawn secondary cyclones over the northern Mediterranean (Vrhovec, 2002). Heavy and intense precipitation at this time of the year can also be induced by Mediterranean cyclones. Due to an orographic effect precipitation during described weather events is significantly enhanced as a result of southwest winds forcing Mediterranean moist air masses to rise over the Alpine-Dinaric barrier (Pristov, et al., 1982).

The absence of intense precipitation and thus significantly lower incidence of flash flooding during meteorological winter and spring are attributed to lower temperatures and lower air humidity in this part of the year preventing the formation of more intense weather events. Convective processes are also less pronounced. Moreover, in winter, precipitation at high altitudes is typically in the form of snow, preventing direct runoff. At this time of the year the polar front with its Mediterranean cyclones is located mostly over the Mediterranean, i.e. more to the south. Consequently, these cyclones have a lesser impact on weather in Slovenia during meteorological winter. Cold air from the north is somewhat heated, when it travels in spring over the partially warmed up mainland of Western Europe, while at this time of year, air over the Mediterranean is not yet completely warmed up. When the air masses meet, the temperature difference between them is fairly small and, therefore, the activity of cyclones and fronts during meteorological spring is also more moderate (Furlan, 1961).

Next we compared the seasonal distribution of flash flooding between more and less distant time periods, with the year 1950 once again serving as a distinction point, after which the vast majority of flash floods that occurred were also recorded. Up until and including 1950, flash floods were primarily a characteristic of meteorological autumn when $56 \%$ of floods with a known month of occurrence took place. Only a bit less than a quarter of flash floods occurred during meteorological summer (24\%), while $12 \%$ and $7 \%$ occurred during meteorological spring and winter, respectively (Figure 3 (c)). It should be noted that during this earlier period a relatively large proportion of floods did not have a known month of occurrence $(24 \%)$, hence the baseline relationship between the individual seasons is most likely somewhat skewed.Regarding floods that occurred after 1950, the situation is significantly different, since most floods (46\%) occurred during meteorological summer. Slightly fewer (45\%) occurred during meteorological autumn (Figure $3(d)$ ). The remaining $10 \%$ occurred during meteorological winter and spring.

Based only on the available past flash flooding data, up until and including 1950, flash floods were primarily a characteristic of meteorological autumn. Post-1950 meteorological summer caught up with and eventually slightly surpassed meteorological autumn in terms of flash flood numbers. As was the case with analysing the frequency of flash flooding over centuries, the real picture of the seasonal distribution of flash floods is also significantly distorted by the lack of sources from the more distant past. We presume that, in the more distant past, more severe, catastrophic and extensive floods that affected a large number of people were more likely to have been recorded. Such floods generally occur in specific synoptic situations that lead to heavy and intense precipitation over a wider area. This is usually a characteristic of meteorological autumn. Certainly there are comparatively fewer records of less extensive, isolated floods occurring in the more distant past, since such floods usually affect a significantly smaller number of people. These are more distinctive of meteorological summer. A lack of documented sources from the more distant past is therefore the most probable cause for the seemingly marked predominance of autumnal flash flooding up until and including 1950. 

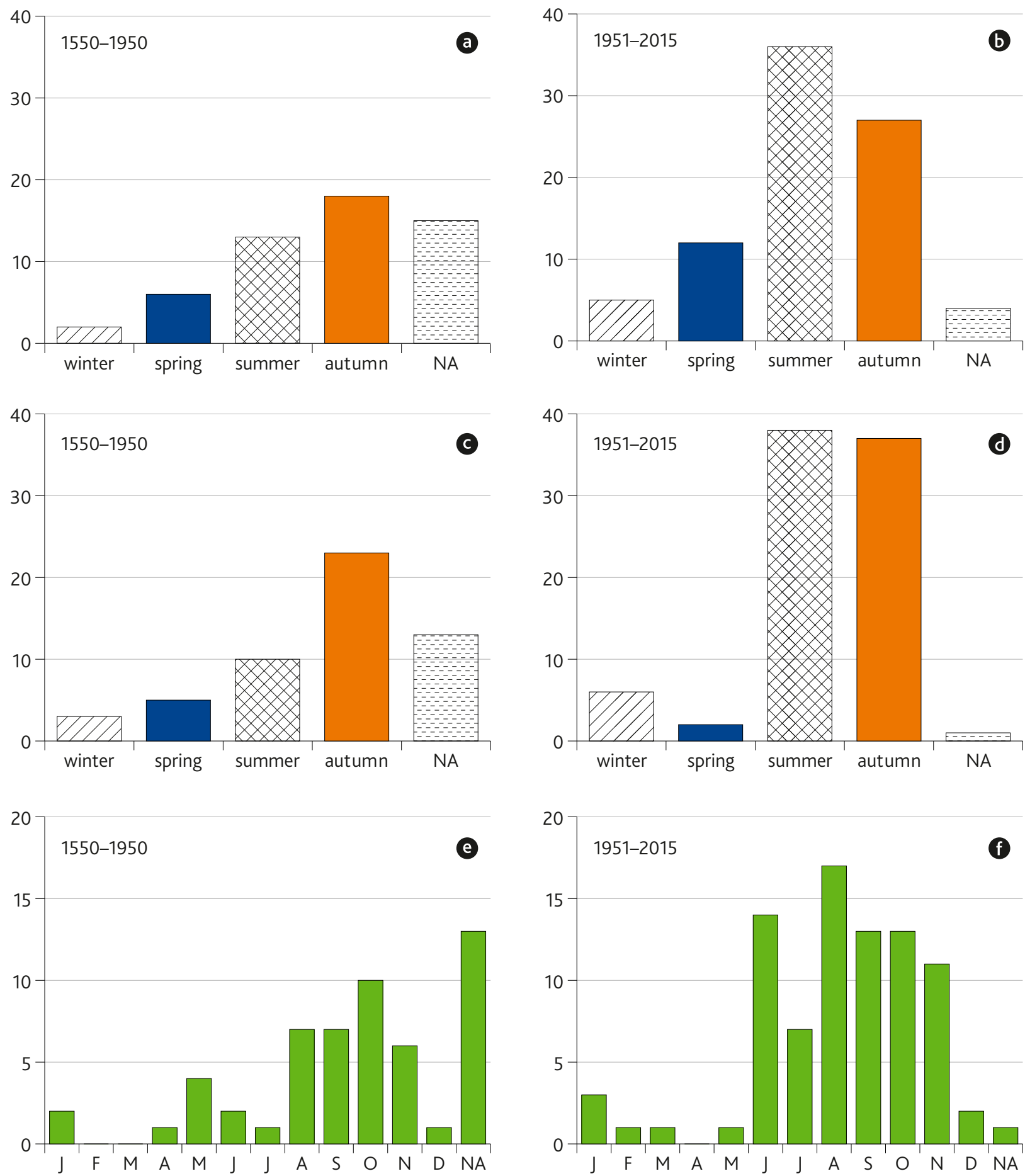

Figure 3: Number of flash floods in Slovenia by month $(e, f)$, meteorological $(c, d)$ and astronomical season (a, b) during different time periods.

Source: author's survey

The real picture of seasonal flash flood distribution can be revealed by analysing only flood events occurring after 1950, as data for this period are more accurate and complete. The period after 1950 is also characterised by a pronounced seasonality of flash floods (Figure 3 (f)). Out of all floods where the month of occurrence was known (83 floods) 90\% occurred between June and November -i.e. during meteorological summer or autumn (Figure $3(\mathrm{~d})$ ). In terms of proportion, meteorological summer had a slight advantage over meteorological autumn, but the difference was insignificant.

The results were slightly different when flash floods were classified according to astronomical (common) seasons, which has so far been the customary way of seasonally distributing floods in Slovenia (e.g. Bat, et 
al., 2003; Brilly, et al., 1999; Kolbezen, 1998; Komac, et al., 2008; Mikoš, et al., 2004). Analysis of floods after 1950 that had a known astronomical season of occurrence (80 floods) shows that summer was most pronounced with $45 \%$ of all floods, followed by autumn with $34 \%$, spring with $15 \%$ and winter with $6 \%$ (Figure 3 (b)). These findings are comparable only to a limited extent to previous published literature on the seasonal distribution of floods in Slovenia. The difficulties arise mainly because this study focused on flash floods only, while others included also karst and riverine floods.

Looking at astronomical (Figure 3 (b)) instead of meteorological seasons (Figure 3 (d)), the differences in the seasonal distribution of flash floods are a larger proportion of spring floods and a smaller proportion of autumnal floods between 1951-2015. The larger proportion of spring floods is mainly due to late astronomical spring floods in June (10 floods) that we classified under meteorological summer. The smaller proportion of autumnal floods is mainly due to the equally large number of late astronomical summer floods in September (10 floods), which we classified under meteorological autumn. A more detailed examination of the causes behind late astronomical spring floods in June and late astronomical summer floods in September showed that the former occurred mainly as a result of strong and relatively short duration confined downpours, otherwise typical of meteorological summer, while the latter occurred mainly as a re- sult of prolonged heavy precipitation over a wider area, otherwise typical of meteorological autumn. It is clear that, compared to astronomical seasons, meteorological seasons coincide considerably more consistently with typical seasonal synoptic weather situations that have the potential to cause heavy and intense precipitation and hence flash flooding. Therefore, we see that by using meteorological seasons as a classifier, it is a lot easier to draw parallels between the seasonal distribution of floods and seasonal weather patterns that cause them.

The question that time will provide an answer to is: how will climate change affect the future seasonal distribution of flash floods in Slovenia? For instance, river discharge regimes have already significantly changed due to higher temperatures and increased evaporation, autumnal increases in precipitation, shallower snow depths, fewer days with snow cover and consequently reduced effects of snow retention (Frantar, Hrvatin, 2005). Moreover, as can be deduced from the accompanying chart which shows the proportion of seasonal floods over a moving 11-year period between 1951 and 2010 (Figure 4), in recent decades there is a small but notable increase in spring and winter flash flooding. Therefore we assume that further rises in temperature along with potential changes in weather types (KajfežBogataj, et al., 2004; Stocker, 2014) could be followed by more intense weather events also during the period when flash floods otherwise occur less frequent-

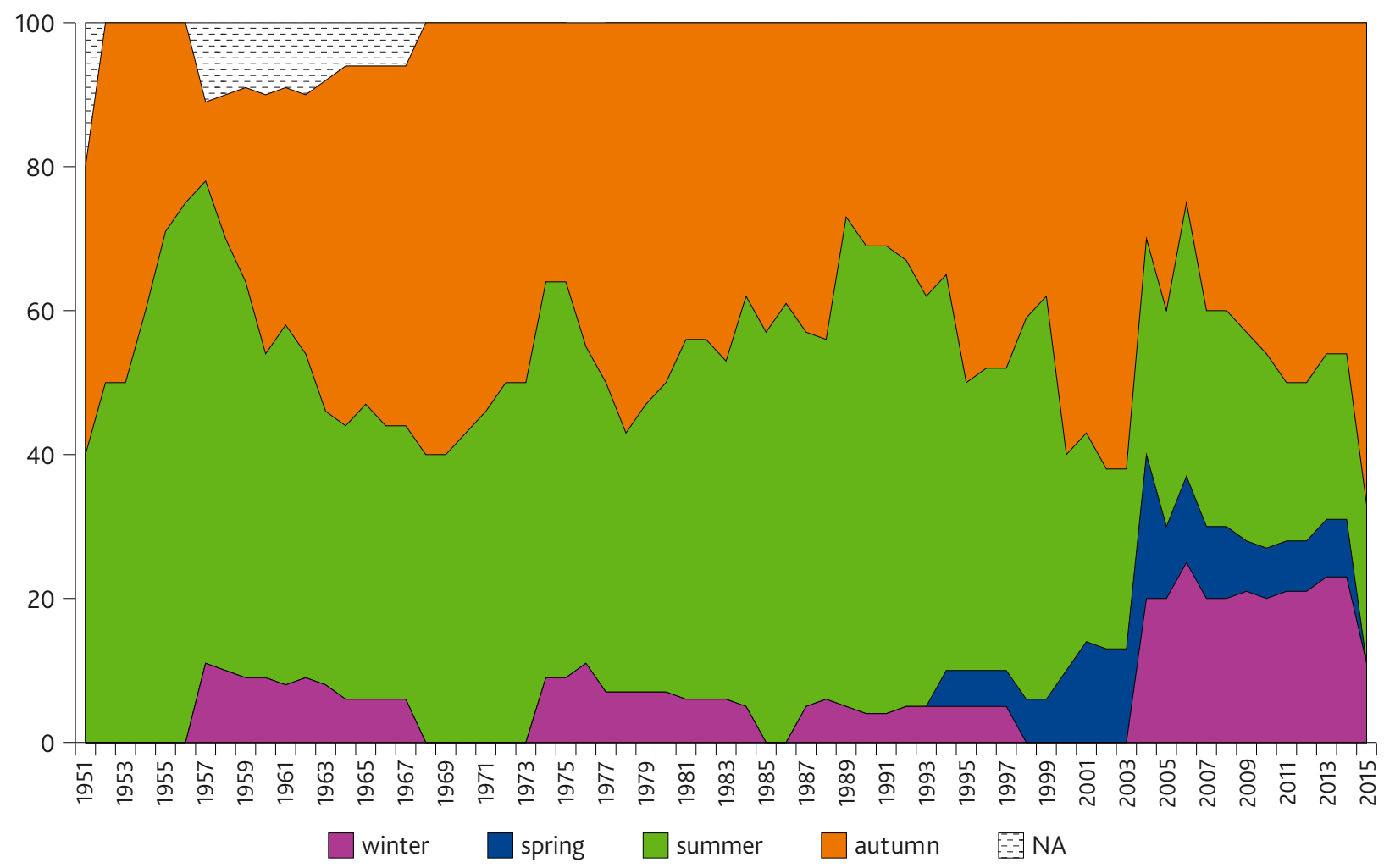

Figure 4. The proportion of seasonal flash floods occurring within a moving 11-year period in Slovenia between 1951 and 2010 Source: author's survey 
ly (the period between December and May). This way the established period of flash flood occurrence in Slovenia would be extended. In this regard the late December floods in 2009, which occurred as a result of heavy rainfall in combination with thaw (the snow line occasionally rose up to $2500 \mathrm{~m}$ ) (Strojan, et al., 2010), are perhaps an indication of an upward trend in winter flooding frequency. Another revealing example is a torrential spring precipitation in May 2014 that caused catastrophic flooding in a considerable part of Bosnia and Herzegovina, Croatia and Serbia (Kobold, et al., 2015), while missing Slovenia by only about a hundred kilometres. Had the cyclone, which caused this precipitation, travelled over a slightly different path, Slovenia would also have been among the affected areas.

\section{Discussion and Conclusions}

Different sources and literature reveal that in Slovenia flash floods occurred relatively frequently also in the past. The question that arises is to what extent has past flash flooding been actually documented and where are the various records stored? Evidently, the further back in time we go, fewer and fewer records of flash floods are preserved. On the other hand, quality and geographically relevant information on floods is preserved in sources dating back as far as the 15th century (Zwitter, 2015). Nonetheless, it generally holds true that for the period before 19th century records on floods in Slovenia have, some exceptions aside, not been accumulated (yet). This does not necessarily mean that they do not actually exist. Various data could probably be found in the archives of different institutions (Zwitter, 2013) which remains a challenge for the future. On account of the previously discussed nature of flash floods, the problem of a lack of data for past flood events of this type is one that is seen universally across Europe (Gaume, et al., 2009) and Slovenia is no exception.

Based on rough comparisons of flood dynamics between earlier and later periods, we estimate that the vast majority of flash floods that affected Slovenia were only actually documented after 1950. Before that, just the more severe and devastating flash floods were documented, as they affected a large number of people and were therefore covered by the media of the day. Consequently, a detailed analysis of the frequency of floods and their seasonal distribution is (for now) sensible exclusively for the floods that occurred after 1950. The results of our research for the period before 1950 could therefore not be set alongside broader international context nor compared with findings from other studies of historical floods in Europe. Consequently, the study also does not allow us to draw possible par- allels between historical periods of more or less frequent flooding (along with their causes) when looking at some neighbouring or nearby countries (e.g. Glaser, et al., 2010; Schmocker-Fackel, Naef, 2010).

In the 1951-2015 period, the frequency of flash floods in Slovenia had, on average, increased. Looking at the linear trendline, which is not actually statistically significant, at the beginning of this period there was on average 1 flash flood per year, while at the end of the period there were already 1.6 flash floods per year. This finding is in line with those reached by Kobold (2011), who noted that in Slovenia, especially in small catchments where flash flooding is common, flow peaks in recent times have increasingly approached record historical levels or even exceed them. It is also possible to draw parallels between the increased number of flash floods in Slovenia and trends of annual peak flows in neighbouring Austria, which since 1976 in catchments smaller than $500 \mathrm{~km} 2$ (according to Gaume, et al. (2009) the arbitrary limit for the occurrence of flash floods) have been mostly positive (Blöschl at al., 2012). On the other hand the first 15 years of the 21st century, which at the same time represent the last 15 years of the studied period, were below average compared to the entire period after 1950 in terms of the number of floods. But on the contrary, at least five flash floods occurred during the said period that were extremely severe and caused a substantial damage. A decline in flash flood frequency in the beginning of 21st century in Slovenia contrasts with the findings of several similar studies elsewhere in Europe. Archer, et al. (2016) for instance found flash flood frequency to have increased in Northeast and Southwest England in the first decade of 21st century. Increases in flash flood frequency between 1999 and 2009 have also been reported for several Central European countries such as Poland, Slovakia and Romania (Bryndal, 2015; Solín, 2008). Such discrepancies only further confirm the existence of significant differences in flood dynamics between different parts of Europe.

Due to the relatively short duration of selected 1951-2015 period (65 years) and the large variability of flash flood events, we cannot provide a definitive answer to the question about possible future changes in their frequency in Slovenia. The observed trends in frequency of flash floods could be extrapolated, although, as Archer, et al. (2015) argue for flash floods in the UK, such projections are not reliable and can only be informative. Based on previous dynamics of flash flooding in Slovenia one can generally expect a roughly similar frequency of flash floods as was in past, i.e. approximately 1.3 flash floods per year. But if doomsday scenarios about future climate changes, which predictan increase in the intensity of precipitation 
and consequently an increase in extreme discharges (Kajfež-Bogataj, et al., 2004; Kobold, 2009; Stocker, 2014) were to play out, the frequency of flash floods and their magnitude should in a long run increase in the future. According to Alfieri, et al. (2015) Slovenia is among the top five European countries that are about to face the most dramatic rise in flood frequency of events with a return period exceeding 100 years. This fact should definitely be taken into account when considering any further interference in the landscape.

As Macdonald (2012) stress, a detailed assessment of long-term flood seasonality requires confidence in the accuracy and completeness of flood records. Given a lack of records for the distant past in Slovenia, comparisons of flash flood seasonality between different periods are difficult to develop with certainty in terms of determining in which season events most often occur. Judging from flash floods that occurred after 1950, meteorological summer is slightly ahead of meteorological autumn in this regard. We note that previous authors addressing the problem of flooding seasonality in Slovenia (e.g. Bat, et al., 2003; Brilly, et al., 1999; Kolbezen, 1998; Mikoš, et al., 2004) put an exaggerated emphasis on spring flooding and paid litthe attention to summer flooding, while we see that the former is actually far less frequent than the latter. This situation comes about probably because according to discharge regimes the majority of Slovenian rivers have one of the peaks in spring (due to snow melting) and one of the lows in summer (a result of substantial evaporation) (Frantar, Hrvatin, 2005). However, past flood experience seems to show that discharge regimes and flood regimes are not necessarily related. Similarly, studying the seasonal characteristics of flood regimes across the Alpine-Carpathian range, Parajka, et al. (2010) noted that extreme events (like flash floods) in certain catchments are likely to occur in particular months regardless of the average occurrence of all annual peaks considered.

Drawing on data from past flood events, one can expect that, in future, the majority of flash floods in Slovenia will occur between June and November due to specific climatic conditions (Ogrin, 1996). Neither are people living on flood prone areas in Slovenia safe from flooding between December and May, since, on average, approximately every tenth flash flood occurs during that period. We assume that raised temperatures caused by climate change and changed weather types (Kajfež-Bogataj, et al., 2004; Stocker, 2014) might be followed by occasionally more intense weather events also during the periods when flash floods are generally less frequent (the period between December and May). Consequently, in the future, flash flooding periods might be prolonged, which is already apparent in the slight increase in frequency of spring and winter floods. Long-term changes in flood seasonality have already been observed by several authors for different parts of Europe (e.g. Blöschl, et al., 2017; Arheimer, Lindström, 2015; Macdonald, 2012; Petrow, Merz, 2009), which suggests that such changes should be taken very seriously.

In literature dealing with the problem of flooding in Slovenia, the seasonal distribution of floods is traditionally presented according to astronomical seasons. In this study we show that, compared to astronomical seasons, meteorological seasons coincide considerably more consistently with typical seasonal synoptic weather situations that have the potential to cause heavy and intense precipitation and hence flash flooding. We recommend that, in order to facilitate the identification of correlations between the seasonal distribution of floods and seasonal weather patterns that cause them future analyses of flood distribution (regardless of their type) also rely on meteorological seasons. Not least since the majority of similar studies also examine seasonality of flooding by focusing on months, groups of months or meteorological seasons.

\section{References}

Alfieri, L., Burek, P., Feyen, L., Forzieri, G. 2015. Global warming increases the frequency of river floods in Europe. Hydrology and Earth System Sciences 19, 2247-2260.

Archer, D.R., Parkin, G., Fowler, H.J. 2016. Assessing long term flash flooding frequency using historical information. Hydrology Research, 48, 1-16.

Arheimer, B., Lindström, G. 2015. Climate impact on floods: changes in high flows in Sweden in the past and the future (1911-2100). Hydrology and Earth System Sciences 19, 771-784.

Barredo, J.I. 2007. Major flood disasters in Europe: 1950-2005. Natural Hazards 42, 125-148.

Bat, M., Dobnikar Tehovnik, M., Mihorko, P., Grbović, J. 2003. Tekoče vode. In: Uhan, J., Bat, M. [eds.], Vodno bogastvo Slovenije (pp. 27-35). Ministrstvo za okolje, prostor in energijo, Agencija Republike Slovenije za okolje, Ljubljana. (in Slovene)

Blöschl, G., Hall, J., Parajka, J., Perdigão, R.A.P., Merz, B., Arheimer, B., Aronica, G.T., Bilibashi, A., Bonacci, O., Borga, M., Čanjevac, I., Castellarin, A., Chirico, G.B., Claps, P., Fiala, K., Frolova, N., Gorbachova, L., Gül, A., Hannaford, J., Harrigan, S., Kireeva, M., Kiss, A., Kjeldsen, T.R., Kohnová, S., Koskela, J.J., Ledvinka, o., Macdonald, N., Mavrova-Guirguinova, M., Mediero, L., Merz, R., Molnar, P., Montanari, A., Murphy, C., Osuch, M., Ovcharuk, V., Radevski, I., Rogger, M., Salinas, J.L., Sauquet, E., Šraj, M., Szolgay, J., Viglione, A., Volpi, E., Wilson, D., Zaimi, K., Živković, N. 2017. Chang- 
ing climate shifts timing of European floods. Science 357, 588-590.

Blöschl, G., Merz, R., Parajka, J., Salinas, J., Viglione, A. 2012. Floods in Austria. In: Kundzewicz, Z.W. [ed.], Changes in flood risk in Europe (pp. 169-177). IAHS Press, CRC Press/Balkema, Wallingford.

Borga, M., Boscolo, P., Zanon, F., Sangati, M. 2007. Hydrometeorological Analysis of the 29 August 2003 Flash Flood in the Eastern Italian Alps. Journal of Hydrometeorology 8, 1049-1067.

Borga, M., Gaume, E., Creutin, J.D., Marchi, L. 2008. Surveying flash floods: gauging the ungauged extremes. Hydrological processes 22, 3883-3885.

Borga, M., Stoffel, M., Marchi, L., Marra, F., Jakob, M. 2014. Hydrogeomorphic response to extreme rainfall in headwater systems: Flash floods and debris flows. Journal of Hydrology 518, 194-205.

Brázdil, R., Kundzewicz, Z.W., Benito, G., 2006. Historical hydrology for studying flood risk in Europe. Hydrological Sciences Journal 51, 739-764.

Brázdil, R., Kundzewicz, Z.W., Benito, G., Demarée, G., Macdonald, N., Roald, L.A. 2012. Historical Floods in Europe in the Past Millennium. In: Kundzewicz, Z.W. [ed.], Changes in flood risk in Europe (pp. 121-166). IAHS Press, CRC Press/ Balkema, Wallingford.

Brilly, M., Mikoš, M., Šraj, M. 1999. Vodne ujme - varstvo pred poplavami, erozijo in plazovi. Fakulteta za gradbeništvo in geodezijo, Ljubljana, 189 pp. (in Slovene)

Bryndal, T. 2015. Local flash floods in Central Europe: A case study of Poland. Norwegian Journal of Geography 69, 288-298.

EEA 2016. Flood risks and environmental vulnerability - Exploring the synergies between floodplain restoration, water policies and thematic policies. European Environment Agency: http://www.eea. europa.eu/publications/flood-risks-and-environmental-vulnerability/at_download/file (15.05.2016)

EM-DAT 2009. The International Disaster Database. Emergency Events Database (EM-DAT): http:// www.emdat.be/advanced_search/index.html (15.05.2016)

Frantar, P., Hrvatin, M. 2005. Discharge regimes in Slovenia from 1971 to 2000. Geographical bulletin 77, 115-127. (in Slovene with English summary)

Frantar, P., Kobold, M., Ulaga, F. 2008. Discharge Trends. In: Frantar, P. [ed.], Water Balance of Slovenia 1971-2000 (pp. 50-60). Ministry for Environment and Spatial Planning, Environmental Agency of the Republic of Slovenia, Ljubljana.

Furlan, D. 1961. Precipitation in Slovenia. Acta geographica 6, 5-160. (in Slovene with English summary)
Gaume, E., Bain, V., Bernardara, P., Newinger, O., Barbuc, M., Bateman, A., Blaškovičová, L., Blöschl, G., Borga, M., Dumitrescu, A., Daliakopoulos, I., Garcia, J., Irimescu, A., Kohnova, S., Koutroulis, A., Marchi, L., Matreata, S., Medina, V., Preciso, E., Sempere-Torres, D., Stancalie, G., Szolgay, J., Tsanis, I., Velasco, D., Viglione, A. 2009. A compilation of data on European flash floods. Journal of Hydrology $367,70-78$.

Glaser, R., Riemann, D., Schönbein, J., Barriendos, M., Brázdil, R., Bertolin, C., Camuffo, D., Deutsch, M., Dobrovolný, P., Van Engelen, A., Enzi, S., Halíčková, M., Koenig, S.J., Kotyza, O., Limanówka, D., Macková, J., Sghedoni, M., Martin, B., Himmelsbach, I. 2010. The variability of European floods since AD 1500. Climatic Change 101, 235-256.

Grams, C.M., Binder, H., Pfahl, S., Piaget, N., Wernli, H. 2014. Atmospheric processes triggering the central European floods in June 2013. Natural Hazards and Earth System Sciences 14, 1691-1702.

Hall, J., Arheimer, B., Borga, M., Brázdil, R., Claps, P., Kiss, A., Kjeldsen, T.R., Kriaučiūnienè, J., Kundzewicz, Z.W., Lang, M., Llasat, M.C., Macdonald, N., Mcintyre, N., Mediero, L., Merz, B., Merz, R., Molnar, P., Montanari, A., Neuhold, C., Parajka, J., Perdigão, R.A.P., Plavcová, L., Rogger, M., Salinas, J.L., Sauquet, E., Schär, C., Szolgay, J., Viglione, A., Blöschl, G. 2014. Understanding flood regime changes in Europe: A state-of-the-art assessment. Hydrology and Earth System Sciences 18, 2735-2772.

Jesenovec, S. 1995. Pogubna razigranost - 110 let organiziranega hudourničarstva na Slovenskem 1884-1994. Podjetje za urejanje hudournikov, Ljubljana, 276 pp. (in Slovene)

Jonkman, S.N. 2005. Global perspectives on loss of human life caused by floods. Natural Hazards 34, 151-175.

Kajfež-Bogataj, L., Bergant, K., Črepinšek, Z., Cegnar, T., Sušnik, A. 2004. Scenarij podnebnih sprememb v Sloveniji kot temelj za oceno ogroženosti z vremensko pogojenimi naravnimi nesrečami $\mathrm{v}$ prihodnosti, zaključno poročilo o rezultatih opravljenega raziskovalnega dela na projektu ciljnega raziskovalnega programa (CRP) Konkurenčnost Slovenije 2001-2006. Biotehniška fakulteta, Oddelek za agronomijo, Ljubljana, 65 pp. (in Slovene)

Kjeldsen, T., Macdonald, N., Lang, M., Mediero, L., Albuquerque, T., Bogdanowicz, E., Brázdil, R., Castellarin, A., David, V., Fleig, A., Gül, G., Kriauciuniene, J., Kohnová, S., Merz, B., Nicholson, O., Roald, L., Salinas, J., Sarauskiene, D., Šraj, M., Strupczewski, W., Szolgay, J., Toumazis, A., Vanneuville, W., Veijalainen, N., Wilson, D. 2014. Documentary evidence of past floods in Europe and 
their utility in flood frequency estimation. Journal of Hydrology 517, 963-973.

Kobold, M. 2006. High waters and floods between August 20 and 23, 2005. Ujma 20, 48-55. (in Slovene with English abstract)

Kobold, M. 2009. The influence of climate change on extreme hydrological events. Ujma 23, 128-135. (in Slovene with English abstract)

Kobold, M. 2011. Comparison of floods in September 2010 with registered historic flood events. Ujma 25, 48-56. (in Slovene with English abstract)

Kobold, M., Globevnik, L., Brilly, M., Vidmar, A., Anzeljc, D. 2015. Hydrological analysis of catastrophic flood that struck Bosnia and Herzegovina in May 2014. Ujma 29, 252-263. (in Slovene with English abstract)

Kolbezen, M. 1991. Velike poplave in povodnji na Slovenskem - I. Ujma 5, 146-149. (in Slovene with English summary)

Kolbezen, M. 1992. Velike poplave in povodnji na Slovenskem - II. Ujma 6, 214-219. (in Slovene with English summary)

Kolbezen, M. 1993. Velike poplave in povodnji na Slovenskem - III, Povodenj v porečju Savinje Junija 1954. Ujma 7, 81-84. (in Slovene with English summary)

Kolbezen, M. 1994. Velike poplave in povodnji na Slovenskem - IV, Poplave leta 1964 in 1965. Ujma 8, 81-87. (in Slovene with English summary)

Kolbezen, M. 1995. Velike poplave in povodnji na Slovenskem - V, Poplave leta 1972. Ujma 9, 227-230. (in Slovene with English summary)

Kolbezen, M. 1996. Velike poplave in povodnji na Slovenskem - VI. Ujma 9, 260-263. (in Slovene with English summary)

Kolbezen, M. 1998. Hidrografija Slovenije. In: Gams, I., Vrišer, I. [eds.], Geografija Slovenije (pp. 139-172). Slovenska matica, Ljubljana. (in Slovene)

Komac, B., Natek, K., Zorn, M. 2008. Geografski vidiki poplav v Sloveniji. Založba ZRC, Ljubljana, 180 pp. (in Slovene with English abstract)

Kundzewicz, Z.W. 2012. Introduction. In: Kundzewicz, Z.W. [ed.], Changes in flood risk in Europe (pp. 1-7). IAHS Press, CRC Press/Balkema, Wallingford.

Kundzewicz, Z.W., Pińskwar, I., Brakenridge, G.R. 2013. Large floods in Europe, 1985-2009. Hydrological Sciences Journal 58, 1-7.

Llasat, M. C., Llasat-Botija, M., Prat, M. A., Porcu, F., Price, C., Mugnai, A., Lagouvardos, K., Kotroni, V., Katsanos, D., Michaelides, S., Yair, Y., Savvidou, K., Nicolaides, K. 2010. High-impact floods and flash floods in Mediterranean countries: the Flash preliminary database. Advances in Geosciences 23, 4755 .
Macdonald, N. 2012. Trends in flood seasonality of the River Ouse (Northern England) from archive and instrumental sources since AD 1600. Climatic Change 110, 901-923.

Madsen, H., Lawrence, D., Lang, M., Martinkova, M., Kjeldsen, T. 2014. Review of trend analysis and climate change projections of extreme precipitation and floods in Europe. Journal of Hydrology 519, 3634-3650.

Marchi, L., Borga, M., Preciso, E., Gaume, E. 2010. Characterisation of selected extreme flash floods in Europe and impication for flood risk management. Journal of Hydrology 394, 118-133.

Melo, M., Pekárová, P., Miklánek, P., Melová, K., Dujsíková, C. 2014. Use of historical sources in a study of the 1895 floods on the Danube River and its tributaries. Geographica Pannonica 10, 190-112.

Merz, B., Vorogushyn, S., Uhlemann, S., Delgado, J., Hundecha, Y. 2012. HESS Opinions »More efforts and scientific rigour are needed to attribute trends in flood time series". Hydrology and Earth System Sciences 16, 1379-1387.

Mikoš, M., Brilly, M., Ribičič, M. 2004. Floods and Landslides in Slovenia. Acta hydrotechnica 22, 113133 .

Mills, E. 2005. Insurance in a Climate of Change. Science 309, 1040-1044.

Modrick, T.M., Georgakakos, K.P. 2015. The character and causes of flash flood occurrence changes in mountainous small basins of Southern California under projected climatic change. Journal of Hydrology: Regional Studies 3, 312-336.

Natek, K. 2007. Geographical dimensions of natural hazards and their prevention. Dela 28, 147-164. (in Slovene with English summary)

Ogrin, D. 1996.The climate types in Slovenia. Geographical bulletin 68, 39-56.

Parajka, J., Kohnová, S., Bálint, G., Barbuc, M., Borga, M., Claps, P., Cheval, S., Dumitrescu, A., Gaume, E., Hlavčová, K., Merz, R., Pfaundler, M., Stancalie, G., Szolgay, J., Blöschl, G. 2010. Seasonal characteristics of flood regimes across the Alpine-Carpathian range. Journal of Hydrology 394, 78-89.

Petkovšek, Z., Trontelj, M. 1996. Pogledi na vreme. Državna založba Slovenije, Ljubljana, 139 pp. (in Slovene)

Petrow, T., Merz, B. 2009. Trends in flood magnitude, frequency and seasonality in Germany in the period 1951-2002. Journal of Hydrology 371, 129-141.

Pińskwar, I., Kundzewicz, Z.W., Peduzzi,P., Brakenridge, G.R., Stahl, K., Hannaford, J. 2012. Changing Floods in Europe. In: Kundzewicz, Z.W. [ed.], Changes in flood risk in Europe (pp. 83-96). IAHS Press, CRC Press/Balkema, Wallingford. 
Pristov, J., Zupančič, B., Štucin, F. 1982. Maximal daily precipitations in the basin of the river Sava. $\mathrm{Pa}$ pers 26, 35-47. (in Slovene with English summary)

Schmocker-Fackel, N., Naef, F. 2010. Changes in flood frequencies in Switzerland since 1500. Hydrology and Earth System Sciences 14, 1581-1594.

SEA 2016. Analysis of extreme hydrological events. Slovenian Environment Agency (SEA): http://www. arso.gov.si/vode/poro\%c4\%8dila\%2oin\%2opublikacije/ (15.05.2016) (in Slovene)

Solín, L. 2008. Analysis of floods occurrence in Slovakia in the period 1996-2006. Journal of Hydrology and Hydromechanics 56, 95-115. (in Slovak with English summary)

Stocker, T. F. 2014. Climate Change 2013: The Physical Science Basis: Working Group I contribution to the Fifth assessment report of the Intergovernmental Panel on Climate Change. Cambridge University Press, New York, $1535 \mathrm{pp}$.

Strojan, I., Kobold, M., Robič, M., Pogačnik, N., Kosec, D. 2010. Floods between 23 and 27 December 2009. Ujma 24, 36-47. (in Slovene with English abstract)

Šifrer, M. 1983. Causes and effects of the river inundations in Slovenia. In: Gams, I. [ed.], Natural disasters in Slovenia as a threat (pp. 41-49). The Slovenian Academy of Sciences and Arts, Ljubljana. (in Slovene with English summary)

Šraj, M., Menih, M., Bezak, N. 2016. Climate variability impact assessment on the flood risk in Slovenia. Physical geography 37, 73-87.
Trobec, T. 2016. Spatio-temporal distribution of flash floods in Slovenia. Dela 46, 21-39.

Trontelj, M. 1997. Kronika izrednih vremenskih dogodkov XX. stoletja. Hidrometeorološki zavod RS, Ljubljana, 135 pp. (in Slovene)

UNISDR \& CRED 2016. The human cost of weather-related disasters 1995-2015. United Nations Office for Disaster Risk Reduction (UNISDR), Centre for Research on the Epidemiology of Disasters (CRED): http://www.unisdr.org/files/46796_cop21weatherdisastersreport2015.pdf (15.05.2016)

Vrhovec, T. 2002. Vreme. In: Ušeničnik, B. [ed.], Nesreče in varstvo pred njimi (pp. 35-41). Uprava RS za zaščito in reševanje Ministrstva za obrambo, Ljubljana. (in Slovene)

Zanon, F., Borga, M., Zoccatelli, D., Marchi, L., Gaume, E., Bonnifait, L., Delrieu, G. 2010. Hydrological analysis of a flash flood across a climatic and geologic gradient: The September 18, 2007 event in Western Slovenia. Yournal of Hydrology 394,182-197.

Zorn, M., Komac, B. 2011. Damage caused by natural disasters in Slovenia and globally between 1995 and 2010. Acta geographica Slovenica 51, 7-41.

Zwitter, Ž. 2013. History of weather and climate in calendars and manorial minutes of Tomaž Hren, bishop of Ljubljana (1597-1630). Historical review 67, 306-389 (in Slovene with English summary)

Zwitter, Ž. 2015.Material responses to natural hazards in 16 th and 17 th centuries: cases from present-day Slovenia and its surroundings. Dela 43, 5-28. 